\title{
Applications of Biological Diversity Information Systems towards Conservation at Lawachara National Park in Bangladesh
}

\author{
Md. Rahimullah Miah ${ }^{1 *}$, Alexander K. Sayok ${ }^{2}$, Ahi Sarok ${ }^{3}$, Mohammad Belal Uddin ${ }^{4}$ \\ ${ }^{1,2}$ Institute of Biodiversity and Environmental Conservation (IBEC), Universiti Malaysia Sarawak (UNIMAS), MALAYSIA \\ ${ }^{3}$ Faculty of Social Science, Universiti Malaysia Sarawak, MALAYSIA \\ ${ }^{4}$ Department of Forestry and Environmental Science, Shahjalal University of Science and Technology, Sylhet, BANGLADESH \\ *Email for Correspondence: 14010140@ siswa.unimas.my
}

\begin{abstract}
The study investigates a framework for Integrated Biological Diversity Information Systems (BDIS) with relevant rules and regulations that emphasize the need for interdisciplinary research collaborations at national, regional and global scales on nature conservation mechanisms at Lawachara National Park (LNP) in Bangladesh. To date, Bangladesh has no Integrated National Biodiversity Database with Clearing House Mechanisms. So, there is a lot of nature conserving problems faced on biodiversity management systems. The study integrates technological information from stakeholders like park manager, biological diversity specialists, network officers, ecological specialists, policymakers, wildlife managers, academicians and relevant bodies. The study represents the uniqueness of the tools used to enhance conservation professionals on the national biodiversity strategic action plan through existing policies and technology, literature reviews, observations, interviews and reconnaissance findings. Approximately $64 \%$ of the respondents agreed for the development of Biological Diversity Information Systems (BDIS) for conserving nature at LNP. The study describes the essential information needed for comprehensive data exchange, data indexing, web-publication and reports on Convention on Biological Diversity with the help of Resources Information Management System. Finally, the study suggests future research trajectories using a new collaborative approach to drive the methodological agenda and recommends ways to further incorporate the information systems integrating next generations' biodiversity conservation perspectives.
\end{abstract}

Key words: Biodiversity, Information Systems, Stakeholders, Lawachara National Park, Bangladesh

This article is is licensed under a Creative Commons Attribution-NonCommercial 4.0 International License.

Attribution-NonCommercial (CC BY-NC) license lets others remix, tweak, and build upon work non-commercially, and although the new works must also

acknowledge and be non-commercial.

\section{INTRODUCTION}

Human beings live in the age of information with modernized technology which can enhances the production, storage, and sharing of information with rules and regulations to make a significant facet of economic, cultural and scientific affairs at scales from local to global (Michael et al., 2006). So, we are experiencing a digital revolution with an information explosion to become individuals highly susceptible to information anxiety or overload (Biggs, 1989; Holtham and Courtney 1999). It is clear that Information Communication and Technology (ICT) has become a driving force in the area of biodiversity conservation and the establishment and management of protected areas (ICEM 2003; Wilson, 2003; Henry and Armstrong, 2004; Dogadernegi, 2014). There is a great deal of academic discourse and debate around theories of the information society (Fuller, 2005) and protected areas. These areas operate with rules and regulations for promoting and harmonizing of biodiversity policy through conservation systems. These systems integrate with Information systems developing dataset biological diversity Information Systems (BDIS). This system is a group of tools which can increase the competitiveness and gain better information for decision making with relevant diversity's system and orders. But till to date, there is no effective national biodiversity database including clearing house mechanisms (CHM) as well as information systems in Bangladesh 
and other local places. Consequently, many organizations decide to implement BDIS to improve the effectiveness and efficiency of their organizations particularly in monitoring protected areas. Researchers in Bangladesh had made several attempts to develop a framework of information systems with biodiversity conservation policy systems in Bangladesh. So, Bangladesh lacks proper information related to conservation and management information systems. Information needs for biodiversity are many and varied (Salem, 2003; Peri et al., 2011) with agencies and localities, and the state of knowledge is all too often unsatisfactory for proper evaluations to be made (Heywood, 1997). Lack of reliable information and sound assessments can cause undesirable consequences for the understanding of biodiversity, thus the need to update rules and regulations and for the development of indicators and indices which permit changes and trends to be observed and transformed over time.

The overall objective of having the mentioned efforts is to enhance the capacity of developing countries for data management with Clearing House Mechanisms ( $\mathrm{CHM)} \mathrm{to} \mathrm{support} \mathrm{the} \mathrm{implementation} \mathrm{of} \mathrm{the} \mathrm{Convention} \mathrm{on}$ Biological Diversity (CBD). A diversity information system should support the assessment and monitoring processes by providing the data needed to describe current environmental baseline conditions, identify the species and habitats at greatest risk, guide land management decisions, and model the effects of alternative conservation policies (Davis et al., 1990; Salem, 2003). Nations, therefore, must have the motivation to develop national information management strategies (needs, sources means of collection, management, and accessibility). However, towards this end, no country has a perfect information management system, with appropriate information available to whoever needs it(Harrison, 1995), but there have been significant developments. For these reasons, this study attempts to develop a framework related to the Biological Diversity Information Systems (BDIS) indicating the Lawachara National Park in Moulvibazar district of Bangladesh.

\section{General Context of the Research}

Biodiversity information systems is a dataset of biodiversity which can be used in its monitoring (Reyers and McGeoch, 2007 ), bioregional planning (Smith and Wolfson, 2004), identifying and categorizing threatened species (Tweddle, et al., 2009 ), understanding the impacts of global change on biodiversity (Coetzer, et al., 2012; Skelton and Coetzer, 2011; Cherry, 2009; Skelton et al., 1995); developing mitigation strategies; informing sustainable harvesting programs; control of alien, invasive species (Foxcroft et al., 2009), ecological niche modeling (Phillips et al., 2006), disease vectors; environmental impact assessments (Coetzer et al., 2012)and decision making on policy status of biodiversity protection. Biodiversity information in specimen databases of natural history museums has seen renewed interest and much innovation and development in the last decade (Bisby, 2000;Soberón and Peterson, 2004;Johnson, 2007; Peterson et al., 2010). Article 7 of the CBD obligates each contracting party 'as far as possible and as appropriate' to identify components of biodiversity important for its 'conservation and sustainable use' (BLI, 2006; UNEP, 1992). The multidisciplinary study of conservation biology was developed in 1944 to connect pure ecology and the practical issues of species and habitat conservation (Soulé and Wilcox, 1980). This discipline incorporates biodiversity and habitat, wildlife management, ecology, genetics, population and social sciences. Because the distribution of plant and animal species identifies no national or political boundaries in the globe, it can be developed with detailed mapping and analysis of geographic features, species distribution and natural resources and relevant tasks through online integrated information systems database either nationally or globally. Conservation biology places a key emphasis on the preservation of biodiversity and this, in turn, means that data on the distribution of endangered species and of suitable habitats for such species in of paramount concern to biologists working in the field. Researchers and educators are being challenged to take information systems to a global level to manage energy resources and embrace environmental sustainability as a core principle (Watson et al, 2010). When all information systems become Geographic Information Systems (GIS), then the challenges of conservation biology were met, and overcome, to create a viable future for all the inhabitants of Earth. It has become so widely established in plant protection in particular, that habitat evaluation and monitoring is now be carried out with a high degree of accuracy so that even rare, endemic species with highly limited habitats can be accurately monitored and assessed for conservation (Krigas et al., 2012).

\section{Information}

During the Fourth World Parks Congress meeting of Protected Areas Managers that recognized the individuals and organizations involved in protected areas' work need better information (Salem, 2003) for making decisions (IUCN, 1993). According to the key to success of the Nature Conservancy's protection efforts is the ability to set clear conservation priorities based on scientific information (Stein, 1997; Salem, 2003). One of the ironies of the information age is that as the technology of delivering information becomes more sophisticated, the possibility of processing them all becomes more remote (Wurman, 1989). The amount of information produced globally is both astounding and increasing. For example, there were five Exabyte of new information was created and stored in 2002 as this value had increased by 30\% per year between 1999 and 2002 (Lyman and Varian, 2003). It is not just only the volume of 
information generated and stored; but, it is the transmission or flow of information also that contributed to our management challenges (Wurman, 1989; Wade, 2006). The internet, wireless communication, and a host of emerging digital media make data proliferation and exchange almost effortless. Rapid changes in information and communication technology (ICT) (Eric, 2015; SUN, 2014) are assembling more information obtainable to more people and places at escalating rates. Filtering and selecting the right information has become a primary task of modern managers including those of protected areas (Michael et al., 2006).Any organized, classified, meaningful data which make in a sense is called information. Information, as we know it today, includes both electronic and physical information. The organizational structure (IM, 2016) must be capable of managing this information throughout the information lifecycle regardless of source or format (data, paper documents, electronic documents, audio, video, etc.) for delivery through multiple channels that may include cell phones and web interfaces (Info M, 2016).

\section{Information Systems}

Information Systems (IS) is a set of interrelated components that collect (or retrieve), process, store, and distribute information to support decision making and control in an organization (Laudon and Laudon, 2010) such as the one shown in Figure 1.

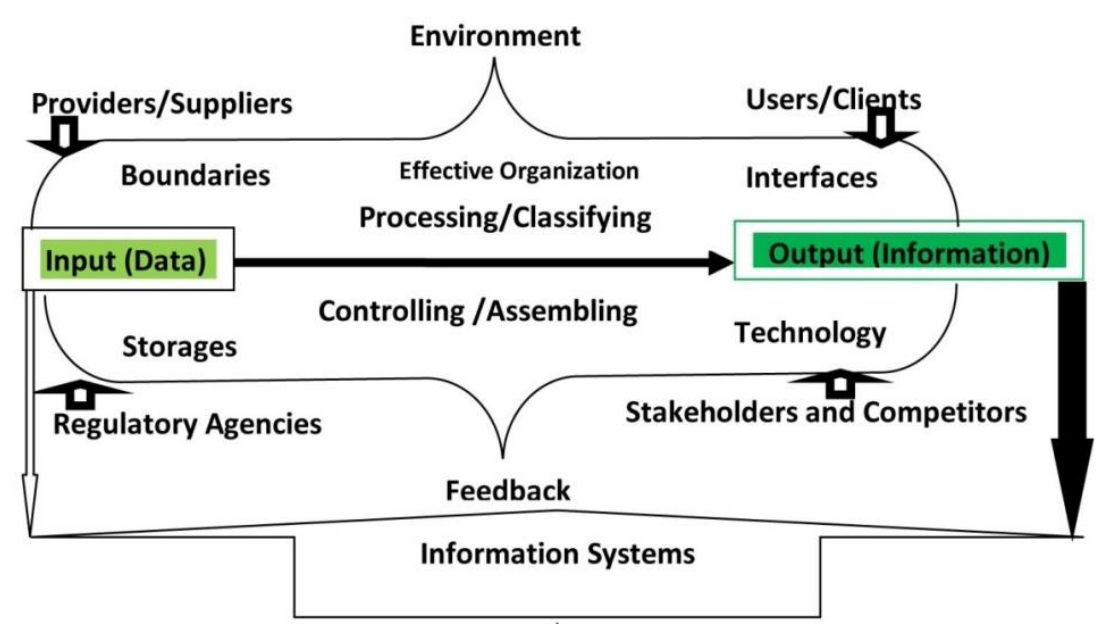

Figure 1: Information Systems with relevant components for storing and retrieving data (Laudon and Laudon, 2010)

Information Systems should be built to support individual, group, and organizational decision making that has the different characteristics, viz. (i) They are flexible and provide many options for handling data and evaluating information (DA, 2016), (ii) They are capable of supporting a variety of style, skills, and knowledge as well as keeping track of many alternatives and consequences, (iii) They are sensitive to the organization's bureaucratic and political requirements, and (iv) Information Systems are building to create corporate value. An Information System represents an organizational and management solution, based on information technology, to a challenge posed by the environment. In protected areas management, information technology for biodiversity includes databases of the species, remote sensing (RS), global positioning systems (GPS) and GIS (Michael et al., 2006; CD, 2016). Information Systems provide amounts of information on a comprehensive scale for an application both as data and software uses conservation biology. Information systems connect with networked information which does not only deliver speedwise answers to scientific demands, but also extends the universe of possible questions on the conservation and sustainable utilization of biological diversity (Canhos et al., 1998).It enhances collaborative and individual research groups to tap into an array of natural resources forward-thinking often for other purposes and operate them for specific research related project as well as practical applications.

\section{Materials AND Methods}

\section{Study Site}

Bangladesh is a developing country with rich biodiversity as it has the world largest deltaic region lies in the northeastern part of South Asia. Total 38 protected areas cover an area of 4,39798.18 ha (about 10.72\% of total forest area), which accounts for $16 \%$ of the total area managed by the Forest Department but less than $2 \%$ of total area of Bangladesh (Hossain, 2001). It includes 17 National Parks, 21Wildlife Sanctuaries and 12 other conservation sites (PAB, 2016) as showed in the Figure 2. The survey was undertaken adjacent villages at Lawachara National Park (LNP), one of four national parks in Sylhet region in the north eastern part of Bangladesh. It declared as a National Park in 1996 with 1,250 hectares of highly diverse hilly evergreen forest under the conservation status of the Wildlife Preservation Act-1974 (This Act revealed and current Wildlife Conservation and Security Act, 2012). The LNP situated in the Union 
and Upozilla of Kamalganj in Moulvibazar district of Bangladesh coordinates with $24^{\circ} 32^{\prime} 12^{\prime \prime} \mathrm{N} 91^{\circ} 47^{\prime} 03^{\prime \prime} \mathrm{E}$. Surrounded all around by human habitats, the park is a critical home for several primate species including the only ape of the country, the Hoolock Gibbon (Hylobateshoolock). The park was also a hotspot for biodiversity to find several species of new and regional record for biodiversity conservation of Bangladesh (Rufford, 2014).

\section{Methods}

The survey on Lawachara biodiversity conservation system was undertaken in four (two inside and other two outside) of the 14 villages around Lawachara National Park. Data related to conservation knowledge, usage of technology, biodiversity conservation policy and protected area management perspectives collected from the respondents. In-depth interviews were conducted with respondents who are the stakeholders (WFP, 2012) involved in Lawachara National Park such as Park Manager, Team Leader of Co-management Committee, Visitors, Indigenous Community Leader, Academics, Biodiversity Specialist, Researchers, Botanists, Zoologists, Learners, Local Government Leaders, Key stakeholders, Policy makers and relevant bodies.

\section{Data Collection}

Data collection methods have employed the study to collect both secondary and primary include observations, semistructured interviews, and questionnaires. Semi-structured interviews were used and selected based on the representation point of view and additionally regarding their relevance to the conceptual questions (Rufford, 2014; FWI, 2012). Furthermore, key informants from the relevant administrative, analyst, professional, environmental lawyers and local users were interviewed on the existing phenomena. Secondary data collected from journals, books, Bangladesh Bureau of Statistics (BBS), Forest Department (FD), Space Research Remote Sensing Organization (SPARRSO), Government institutions (Forest department, Ministry of Environment and Forests, Forest College and Training Centre, Universities, International /National-NGOs, Stakeholders and relevant other sources.

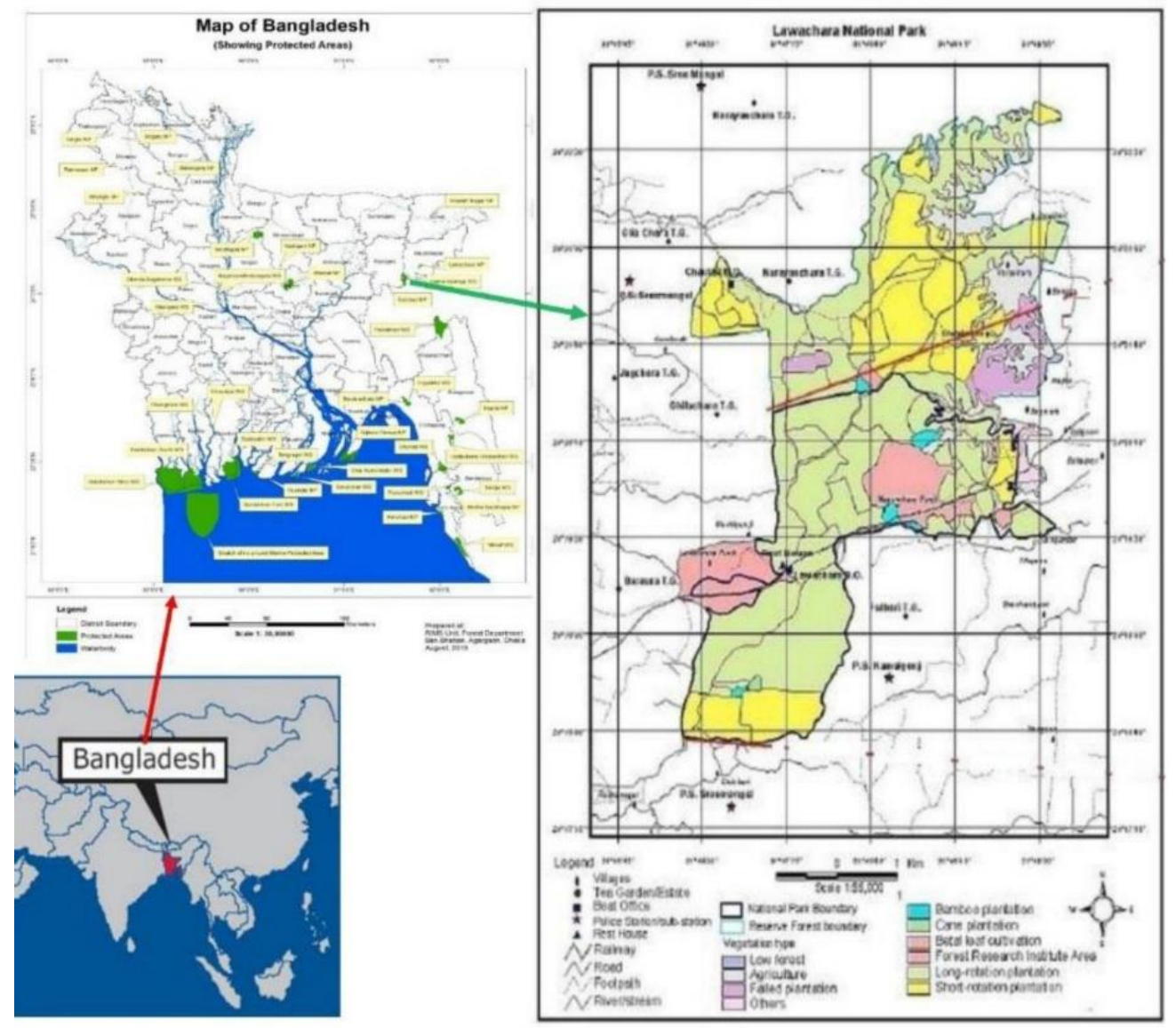

Figure 2: Showing the study area of Lawachara National Park with all Protected Areas in Bangladesh (NSP, 2005)

\section{Data Compilation}

At first, all the general information regarding the occurrence of biodiversity and informatics including biodiversity conservation systems in the Lawachara National Park and their diversity, status, and distribution are collected and tabulated in an organized manner. After the data had been collected, they were checked properly for accuracy, by 
using the crosschecking method, i.e. checking the same information from the different sources and verify the sources of information. Information regarding the initiatives of the authority towards the conservation of biodiversity was also collected through different relevant secondary information and field survey, which carefully compiled and evaluated (FWI, 2012). Then the information included preparation of data mastersheet and their manipulation into convenient forms used in the result and discussion section subsequently. The primary and secondary data compiled with the renowned the MS Excel and relevant software.

\section{Data Handling and Analysis}

Data obtained from the field were analysed usingstandard data analysis software following methods suggested by Emeka et al. (2014). In this study, deductive strategies were used to present the results that ascertained through the interpretations made with the combined Supervisor and Investigator after collecting the data, organizing the data, classifying the data and then figuring out the relationships that existed (Rufford, 2014)using the relevant software, like such as MS Excel, SPSS, MS Access, Operating System and update software on conservation systems.

\section{RESULTS AND Discussion}

Biodiversity is important in our life. However, we cannot perform a single task without its information. Biodiversity information is essential to the respondents in the study areas are shown in the Figure 3 . About the $55 \%$ of the respondents opined their opinions as very essential and $42 \%$ as essential with only $1 \%$ 'No Comment' While much biodiversity and ecosystem information presently exist and much more is composed on a periodic basis, it is still not possible for all those who could benefit from having access to this information to locate, retrieve, integrate, and apply (Otago, 2014; Randow, 2012)it in any reliable approach. In many cases, public and private funds are unknowingly spent on re-collecting information that may actually already exist in some undocumented or unavailable fashion. Much existing biodiversity and ecosystems information cannot be widely used (Randow, 2012) at the protected area because it has not yet converted into an electronic (computerized) format. In most cases, because of different formats, conventions, or technologies, it is difficult to truly integrate information from more than one source or system (Otago, 2014; Randow, 2012). An important issue is determining how to use this information to best predict existing species biodiversity among sets of areas (Stein, 1997).

\section{Importance of Biodiversity Information}

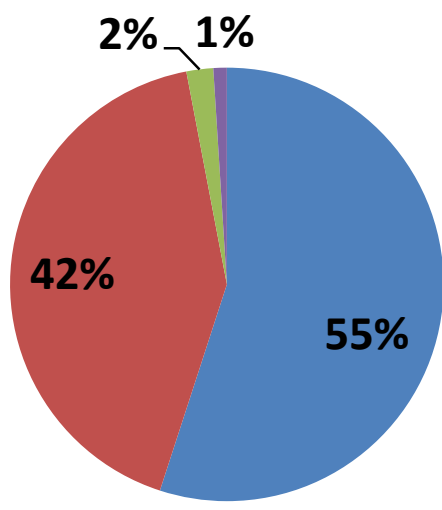

Very Essential

Essential

Approximately

No comment

Figure 3: Importance of Biodiversity Information applying in the Lawachara National Park

\section{Research Role Identification on Biological Diversity Information Systems (BDIS)}

Research Role Identification on Biological Diversity Information Systems (BDIS) plays an important role in researches on biodiversity and conservation especially in the field of natural science and technology that deals with the impact of activities on eco-systems. In the Figure4, it can be seen that about 58respondent who are academic staff performed utilizing BDIS for their research activities sturdily for sustainable protected area management, compared to only two postgraduates/post doctorates for their researches. From another study, we know that indigenous community people may have specific knowledge of endangered species within Lawachara National Park (LNP) which can improve the level of awareness of conservation biologists, scientists and researchers. It is, consequently, required to spread perception of the need to treat biological resources as capital assets and invest accordingly to prevent their depletion (Salem, 2003; CBD, 2016) at Lawachara National Park. 


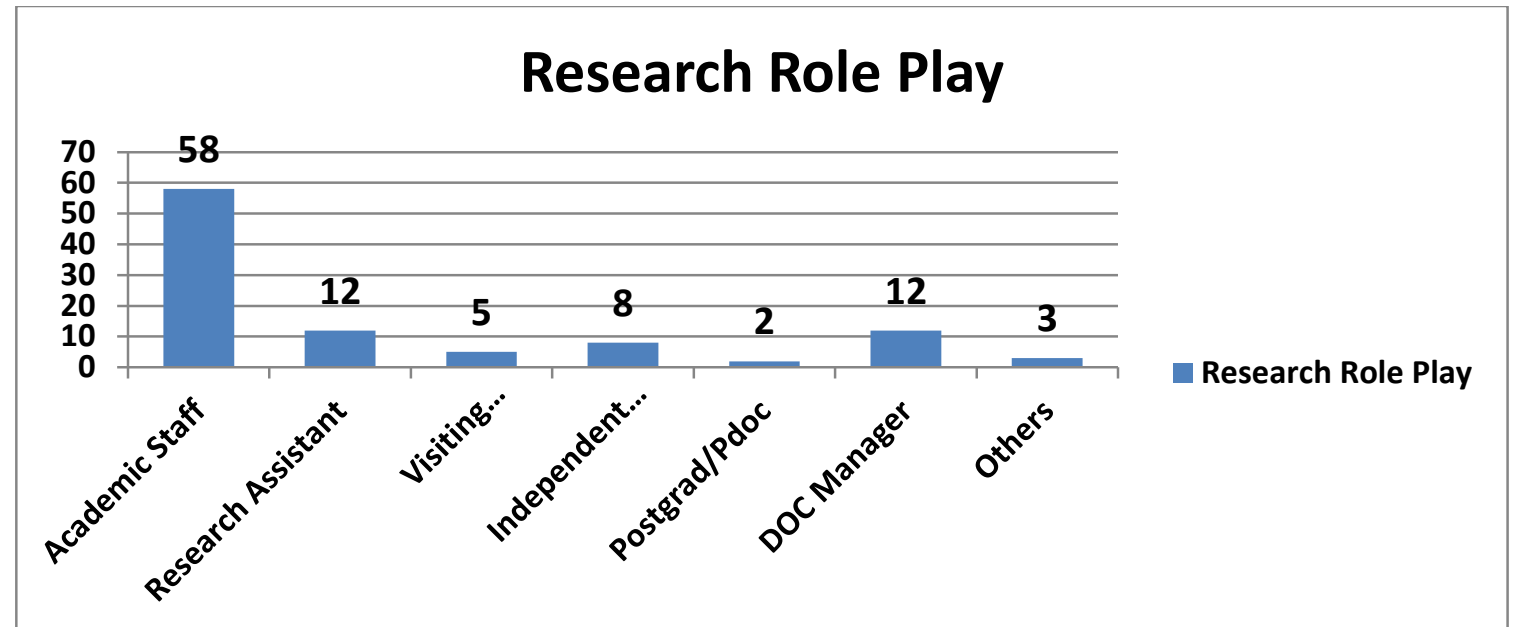

Figure 4: Research Role Play among Stakeholders on Biological Diversity Information Systems for Conserving Biodiversity at the Lawachara Protected Area Management

\section{Knowledge of Respondents in Biological Diversity Information Systems}

Knowledge of Respondents in Biodiversity Information Systems (BDIS) is imperative, because, with the knowledge on BDIS, they need to know the worth of relevant database that deals with the input, processing, and output with the technology and information systems. Figure 5 shows that about $43 \%$ of respondents have simple knowledge for more informed research knowledge towards sustainable protected area management as compared to $11 \%$ of respondents who claimed that are 'more informed' of the BDIS.

\section{Knowledge of Respondents on BIS}

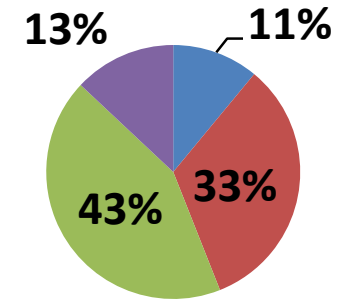

More Informed

Informed

Simple

Nothing

Figure 5: Knowledge of Respondents in Biological Diversity Information Systems (BDIS) for Conserving and Promoting the Biodiversity at the Lawachara National Park

The results revealed that BDIS implementation performed surrounding challenges which were mainly concern management, administration, and people involved in BDIS application processes. Additionally, it can be concluded that the key issues which the BIS implementation project should present with primarily focused on the project team and their team work. The last main finding is concentrated on effects and consequences, and it found out that BIS implementation mainly affects the mentioned process which leads to change, for instance situation, routines, recent advancements in information technology application, national biodiversity and protected area databases, related system database design, research evaluation, ecological monitoring, public rendezvous, data security and so forth at LNP in the north-eastern part of Bangladesh.

\section{Integrated Biological Diversity Information Systems-Online Biodiversity Conservation Database}

Biodiversity conservation database can be constructed to predict where survey efforts may be targeted, to be used as substitutes for full assessments of species in an analysis of biodiversity at a regional scale, and to predict possible impacts of environmental changes (CBD, 2016; Aspinall, 1995). Integrated Biological Diversity Information Systems (IBDIS) is a central database which interlinked with Ministry of Environment and Forests including Bangladesh Forest Department and Directorate of Environment. It is the application of information systems that helps to improve management, operation, monitoring, sharing, discovery, exploration and analysis of the biodiversity. It builds on the foundation of taxonomic, biogeographic and ecological information stored in digital form. The database stores information on visitor's catalog, vegetation mapping with the connection of Regional Navigation Satellite System (RNSS) interlinked with Space Research Remote Sensing Organization (SPARRSO). Therefore, other 
stakeholders can utilize the IBDIS according to their requirements as indicated in Figure 6 below. A particular value of IBDIS is to identify organisms which can be used as bio-indicators of ecosystem health and provide early warning of changes in protected and other areas (CBD, 2016; Hawksworth, et al., 1992).

\section{Concept of BIS Database Security}

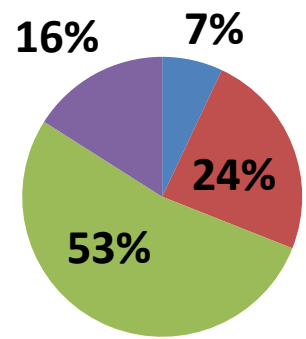

More Secure

Secure

Less Secure

No Idea

Figure 6: Conceptual Idea of Biological Diversity Information Systems (BDIS) Database Security for Developing Research Work on Biodiversity at the Lawachara National Park.

\section{Security of Biological Diversity Information Systems (BDIS) Database}

All data base need proper safety for its effective and efficient operations. But in Bangladesh about 53\% respondents were of the opinion that they will be less secure because of virus, spam, cookie, malware and so on with the obsolete technology and information systems, compared to only $7 \%$ who were of the opinion that BIS database more secure which showed in Figure 6. This research also wish to explore Biodata with the BDIS awareness and status linkages with lawyers, policy makers, government officials, academics, researchers, visitors, decision-makers and relevant stakeholders with tools connecting to update technological arena with the help of computer-based Resources Information Management System (RIMS) unit in Forest Department for promoting and harmonizing the existing nature conservation policies in Bangladesh. The study also investigates the actual indicators/instruments and regulatory framework of the available conservation operations and policies related to biodiversity safeguarding at Lawachara National Park in Sylhet division of Bangladesh. These research efforts have resulted in the study of Biodiversity Information Systems, which support an elaborate global protected area network particularly national parks. The National Biodiversity Strategic Action Plan (NBSAP), Program of Work (POW) and Access to Benefit Sharing (ABS) and to integrate the available methods and the better use of existing information in a complementary manner. This information is needed to develop new strategies for different species because users require biodiversity information on the context of which and the issues on which they need to focus. They also want options backed by documents, maps, and expert opinion (CBD, 2016).

\section{CONCLUSION}

The study shows that biodiversity information is essential to the stakeholders of Lawachara National Park in Bangladesh to enable them to help the protected areas for maintaining biodiversity, securing habitats and reducing threats with evaluating the system effectiveness of nature conservation policy. The Biological diversity information systems (BDIS) being used in the study to identify and conserved at protected areas for the present and future generations is essential because it is a user-friendly system that helps to address both scientific and social issues around the protected areas. Furthermore, it is essential for informed decisions for the sustainable development of biotic resources and the ecosystems that harbor those (Burger et al., 2009) as per required laws and regulations. However, this calls for uniform spread and accessibility of such data. Still, BDIS is not up to date and its application not uniforms throughout the country. There is no mechanism to measure our progress that can encourage demanddriven and deterministic investment in achieving uniform improvement in BDIS (BMC, 2014).It is believed that such uniform advancement will help to reduce the existing imbalance of accessibility to biodiversity and legal issues at Lawachara National Park. Further investigations in stabilizing and enriching the BDISs are essential to implement for promoting and harmonizing biodiversity in protected area in the north-eastern part of Bangladesh. This biodiversity database system can be operated smoothly by the National Park Manager, Academia, Biodiversity Specialist, Scientist, Network Technologist and relevant researchers. Finally, we suggest that future research trajectories of a new kind collaborative approach to drive the methodological agenda and recommendations for further incorporation of the biological diversity information systems from which biodiversity conservation policy can potentially combine with the essential mechanisms in the science-policy-society interface for conserving biodiversity not only at national parks in Bangladesh but worldwide. 


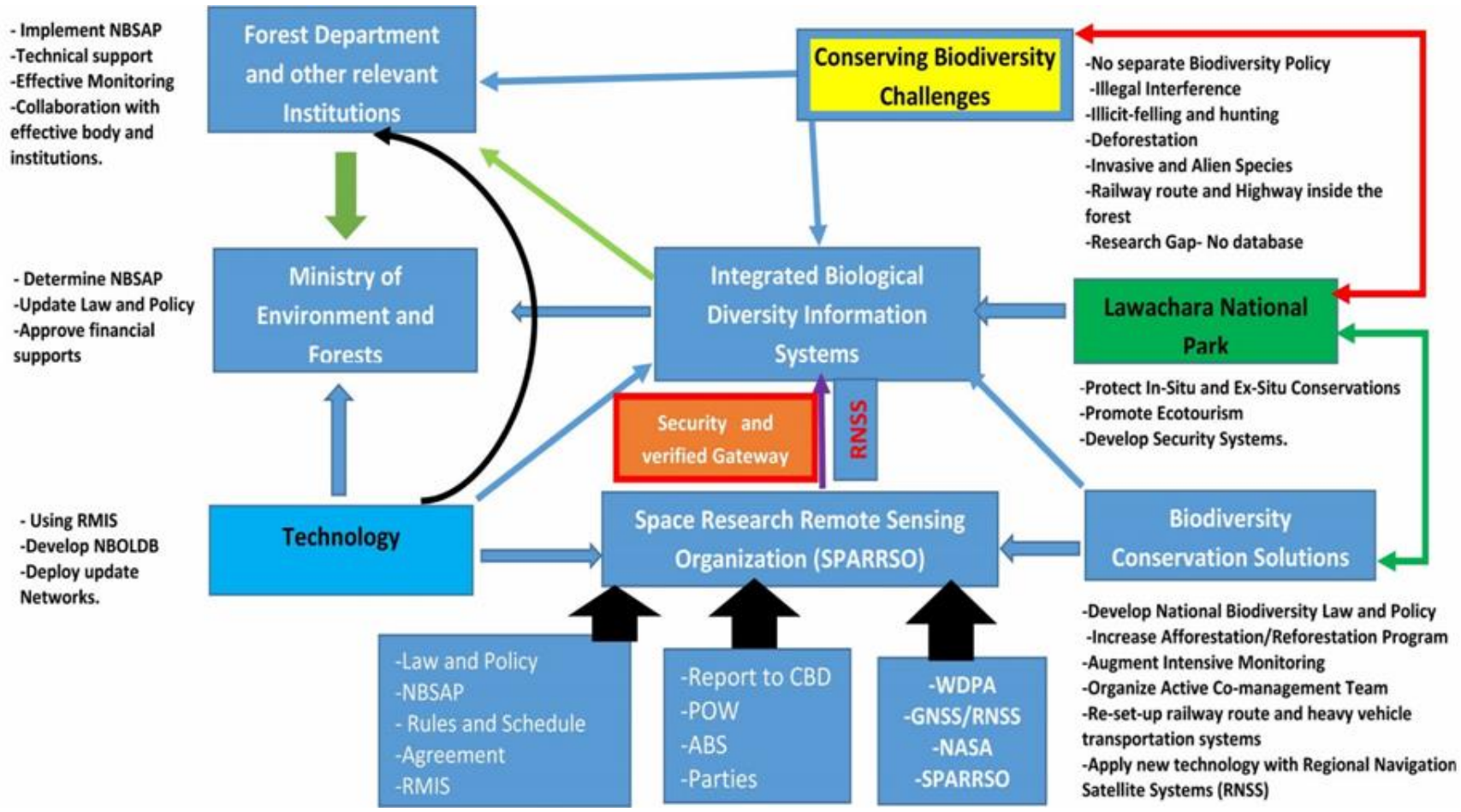

Figure 7: Showing the framework on integrated Biological Diversity Information Systems (IBDIS) at Lawachara National Park

\section{ACKNOWLEDGEMENT}

We are grateful to the Authority of Universiti Malaysia Sarawak (UNIMAS), Malaysia and Information and Communication Technology (ICT) Division of the People's Republic of Bangladesh for providing partial financial support during the field survey and also for feedbacks on the research work. Special thanks to the Authority of Jalalabad TT College, Sylhet affiliated with National University, Bangladesh for providing me the study leave and other necessary supports for this higher study abroad.

\section{REFERENCES}

AIIM (Association for Information and Image Management). (2016). What Does That Mean? What is Information Management?. url: www.aiim.org/What-is-Information-Management.

Arino, A.H.; Chavan, V.; King, N. (2011). The Biodiversity Informatics Potential Index. BMC Bioinformatics. 12 (Suppl 15): S4. url: www.biomedcentral.com/1471-2105/12/S15/S4.

Aspinall, R.J. (1995). Geographic information systems: their use for environmental management and nature conservation. Parks, 5: 20-31. url: www.cbd.int/doc/articles/2003/A-00152.pdf.

Bhardwaj, R.K. (2012). Online Legal Information Systems in India: a Case Study from the Faculty of Law, University of Delhi. Legal Information Management, Vol.12 (2), pp 137-150. Doi: 10.1017/S1472669612000357. url: http://journals.cambridge.org/abstract_S1472669612000357

Biggs, M. (1989). Information Overload and information seekers: What we know about them, what to do about them. url www.eric.ed.gov /?id=EJ407208. The Reference Librarian 25/26, 411-429.

Bisby, F.A. (2000). The quiet revolution: Biodiversity informatics and the Internet. Science 289: 2309-2312. url: www.journals.ku.edu/index.php/jbi/article/viewFile/4263/4038.

BLI (Birdlife International). (2006). Monitoring Important Bird Areas: A Global Framework, Cambridge, UK. Birdlife International Version 1.2. url: www.birdlife.org/datazone/usefiles/file/IBAs/AfricaCntryPD.

BNP (Banff National Park). (1994). Case Study: The Banff-Bow Valley Study and Information Technology, Canada.

Burger, A.; Romano, P.; Paschke, P.; and Splendiani, A. (2009). Semantic Web Applications and Tools for Life Science. BMC Bioinformatics. 10 (Suppl 10). url: http://bmcbioinformatics.biomedcentral.com/articles/supplements/volume-13supplement-1

Canhos, V.P., Manfio, G.P. and Canhos, A. (1998). Networks for distributing information. In: Hawksworth, D.L., Kirk, P.M. and Clarke, S.D. (Eds), Biodiversity Information Needs and Options, Proceeding of the 1996 International Workshop on Biodiversity Information. La: CAB International. 194 pp. url: www.cbd.int/doc/articles/2003/A-00152.pdf. 
CBD (1992). Convention on Biological Diversity. Text and Annexes, the Interim Secretariat for the CBD Geneva. url: www.cbd.int/doc/drafts/guidelines-ia-en.doc.

CBD (Convention on Biological Diversity). (2016). Application of GIS to biodiversity monitoring [Author-B.B. Salem]. Articles. url: www.cbd.int/doc/articles/2003/A-00152.pdf.

CD (Consultation with Diagnosis). (2016, August 29). url:https://www.rainbowtreecare.com/residential-treecare/consultingdiagnosis/what-is-a-consultation-diagnosis /

Cherry, M.I. (2009). What can museum and herbarium collections tell us about climate change? South African Journal of Science 105:87-88.

Coetzer, W., Gon, O., Hamer, M., Allie, F. P. (2012). A New Era for Specimen Databases and Biodiversity Information Management in South Africa. Biodiversity Informatics, 8, 2012, pp.1-11. url: www.journals.ku.edu/index.php/jbi/article/viewFile/4263/4038.

DA (Designing Automobile). (2016, August 20). url:https://www.coursehero.com/file/pmdffv/designing-a-new-automobileonce-the-task-is-accomplished-the-individuals-join/

Davis, F.W., Stoms, D.M., Estes, J.E., Scepan, J. and Scott, J.M. (1990). An information systems approaches to the preservation of biological diversity. International Journal of Geographic Information Systems, 4: 55-78. url: www.cbd.int/doc/articles/2003/A-00152.pdf.

Dogadernegi. (2014). url: http://www.dogadernegi.org/en/turkeys-kbas/ http://www.tandfonline.com/doi/abs/10.1080/21513732.2016.1182949?journalCode=tbsm21 \

Dolin, Ron A. (2010). "Search Query Privacy: The Problem of Anonymization" Hastings Science and Technology Law Journal, p.137. url: www.papers.ssrn.com/sol3/papers.cfm?abstract_id=1620198.

Emeka, N; Akogwu, C.I; Ugwu, J.N. and Emeka, N.C. (2014). Cost-return Analysis of Cocoyam Marketing in Nsukka Agricultural Zone, Nigeria. Sky Journal of Agricultural Research, Vol. 3(11), pp215-222. url: www.skyjournals.org/sjar/pdf/2014pdf/Dec/Emeka\%20et\%20al\%20pdf.pdf

ERIC. (2015). url: www.eric.gov/?id=EJ809329

Faith, D.P. and Walker, P.A. (1996). Environmental diversity: on the best-possible use of surrogate data for assessing the relative biodiversity of sets of areas. Biodiversity and Conservation, 5: 399-415. url: www.cbd.int/doc/articles/2003/A-00152.pdf.

Foxcroft, L.C., D.M. Richardson, M. Rouget, and S. MacFadyen. (2009). Patterns of alien plant distribution at multiple spatial scales in a large national park: implications for ecology, management, and monitoring. Diversity and Distributions 15:367-378. url: www.journals.ku.edu/index.php/jbi/article/viewFile/4263/4038.

Fuller, S.(2005). Another sense of the information age. Information, Communication and Society, 8(4), 459-463.

FWI (Framework on Internet). (2012). url: www.journals.abc.us.org/index.php/abr/article/download/Miah/186

Harrison, J. (1995). Finding the information. Parks, 5: 12-19.

Hawksworth, D.L., Kirk, P.M. and Clarke, S.D. (1992), Biodiversity Information Needs and Options, pp. 5-20. CAB International. 194 pp. url: www.cbd.int/doc/articles/2003/A-00152.pdf.

Henry, M., and L. Armstrong, eds. (2004). Mapping the Future of America's National Parks: Stewardship Through Geographic Information Systems. Redlands: Esri Press. url: https://www.nps.gov/gis/documents/G11613_AU_ESRIPressS_0304.pdf

Heywood, V.H. (1997). Information needs in biodiversity assessments: from genes to ecosystems. In: Hawksworth, D.L., Kirk, P.M. and Clarke, S.D. (Eds), Biodiversity Information Needs and Options, pp. 5-20. Proceedings of the 1996 International Workshop on Biodiversity Information. La: CAB International. 194 pp. url: www.cbd.int/doc/articles/2003/A-00152.pdf.

Holtham, C., and Courtney, N. (1999). Perspectives on information overload. Aslib Proceedings 51 (8), 249-256.

Hossain, M.K. (2001). Overview of the forest biodiversity in Bangladesh. In: Assessment, conservation and sustainable use of forest biodiversity (CBD Technical Series no. 3). Secretariat of the Convention on Biological Diversity, Montreal, 33-35 pp.

ICEM (International Centre for Environmental Management). (2003). Information and protected areas. In Lessons learned from Global Experience. Review of protected areas and development in Lower Mekong River Region. Pp. 102-114. Indooroopilly, Queensland, Australia: ICEM.

IM (Information Management). (2016, August30). Information Systems. url: www.aacsystems.co.uk/information-management/

Info.M (Information Management). (2016, August 25). Information Management and Business Intelligence. url: www.lesuro.com/

IUCN (1993). Parks for life. Report of the IVth World Congress on National Parks and ProtectedAreas. Gland, Switzerland: IUCN, 260 pp. url: www.cbd.int/doc/articles/2003/A-00152.pdf.

Johnson, N.F. (2007). Biodiversity informatics. Annual Review of Entomology 52:421-38.

Khan, D.K. (2015). Legal Information System: A Model Framework for Indian High Courts. Social Science and Humanities Journal. Pp.1-10. DOI: 10.1234.67/sshj.1003. url: http://everant.in/images/sshjissue/v1-i1/3.pdf

Kornkaew, A. (2012, May). Management Information Systems- Implementation Challenges, Success Key Issues, Effects and Consequences: A Case Study of Fenix System. Jokoping International Business School, Jonkoping University. url: www.divaportal.org/smash/get/diva2:545644/FULLTEXT02

Krigas, N., Papadimitriou, K., andMazaris, A. D. (2012). GIS and Ex-situ Plant Conservation. In B. M. Alam,Application of Geographic Information Systems. url:https://www.gislounge.com/gis-used-conservation-biology/ 
Laudon, Kenneth C., and Laudon, J.P. (2010). Information Technology Infrastructure. Management Information Systems: Managing the Digital Firm [11th Edition]. Pearson Prentice Hall, USA. P.187. url: http://www.pearsonmiddleeastawe.com/pdfs/SAMPLE-MIS.pdf

Lyman, P., and Varian, H.R. (2003). How much information. Retrieved on May 30, 2006, url: www.sims.berkeley.edu/how-muchinfo-2003.

McNeely, J.A. (1994). Protected areas for the 21st century: working to provide benefits to society. Biodiversity and Conservation, 3: 390-405.

Michael, S., Quinn and Shelly M. Alexander.2006. Information Technology and the Harmonization of Biodiversity in Protected Areas. Transforming Parks and Protected Areas: Policy and Governance in a Changing World, Chapter 4. [Kevin S. Hanna, Douglas, A., Clark and D. Scott Slocombe], Routledge- Taylor and Francis Group, New York, USA. P.66. URL: http://people.duke.edu/ lcampbe/docs_lmc/Campbell_2008_ParksProtectedAreas.pdf

Miller, A.B. 2001. Managing data to bridge boundaries. In D. Harmon [Editor], Crossing Boundaries in Park Management: Proceedings of the $11^{\text {th }}$ conference on Research and Resource Management in Parks and on Public Lands, pp.316-320. Hancock, MI: The George Wright Society. URL: www.lib.znate.ru/docs/index-7246.html?page=5.

NSP. (2005). Site Strategy for Lawachara National Park. Nishorgo Support Project. BFD-USAID/IRG, Dhaka.

Otago. (2014). URL: https:/ / ourarchive.otago.ac.nz/bitstream/handle/10523/198/2008_OBDMP_questionnaire.pdf?sequence=1andisAllowed=y PAB (Protected Areas of Bangladesh), URL:http://www.bforest.gov.bd/index.php/protected-areas.

Pearce, D.W. and D. Moran. 91994). The Economic value of Biodiversity. London: IUCN andEarthscan Publications Ltd.

Peri, P.L.; Arena, M.; Pastur, G.M. and Lencinas, M.V. (2011). Photosynthetic response to different light intensities, water status and leaf age of two Berberis species of Patagonian steppe. Journal of Arid Environments. 75 (2011):1218-1222. URL: www.sciencedirect.com/science/article/pii/S014019630190..

Peter W. Martin, "Digital Law: Some Speculations on the Future of Legal Information in Technology," http:/ / www.law.cornell.edu/papers/fut95fnl.htm. And www2.arnes.si/ rzjtopl/usa/lawssourc.htm.

Peterson, A.T., S. Knapp, R. Guralnick, J. Soberón and M.T. Holder. 2010. The big questions for biodiversity Informatics.URL: www.journals.ku.edu/index.php/jbi/article/viewFile/4263/4038. https:/ / kuscholarworks.ku.edu/bitstream/handle/1808/13674/soberon2010QUESTIONS.pdf;sequence=1

Phillips, S., R. Anderson, and R. Schapire. 2006. Maximum entropy modeling of species geographic distributions. Ecological Modelling 190:231-259.

Randow, D. (2012). Biodata Management Framework. Dataversity. TFBIS Project 263, Working Draft, Phase two. URL: http:/ / dataversity.org.nz/groups/dataversity_public_discuss/files/f/25WR4LkqOb6qYXqErPS8mjCH7J7-DQt2nOTIum/Biodata\%20Management\%20Framework\%20121130.pdf

Reyers, B. and M.A. McGeoch. 2007. A biodiversity monitoring framework for South Africa: progress and directions. South African Journal of Science, 103:295-300. URL: www.journals.ku.edu/index.php/jbi/article/viewFile/4263/4038.

Rufford. (2014, August 19). URL: http://www.rufford.org/files/75.07.05\%20Detailed\%20Final\%20Report.doc

Salem, B.B., 2003. Application of GIS to biodiversity monitoring, Journal of Arid Environments (2003) 54: 91-114. doi:10.1006/jare.2001.0887. and URL: http://www.sciencedirect.com/science/journal/01401963/54/1

Skelton, P.H., and W. Coetzer. 2011. Changing patterns of freshwater fish diversity in South Africa. Pp. 190-192 in Observations on Environmental Change in South Africa (L.Zietsman (Editor). Sun Press, Stellenbosch. URL: www.journals.ku.edu/index.php/jbi/article/viewFile/4263/4038.

Skelton, P.H., J.A. Cambray, A. Lombard, and G.A. Benn. 1995. Patterns of distribution and conservation status of freshwater fish in South Africa. Proceedings of the Zoological Society of Southern Africa 1994 30:71-81. URL: www.journals.ku.edu/index.php/jbi/article/viewFile/4263/4038.

Smith, G.F. and M.M. Wolfson. 2004. Mainstreaming biodiversity: The role of taxonomy in bioregional planning activities in South Africa. Taxon 53:467.

Soberón, J. and A.T. Peterson. 2004. Biodiversity informatics: managing and applying primary biodiversity data. Philosophical Transactions of the Royal Society B 359:689-698. URL: www.journals.ku.edu/index.php/jbi/article/viewFile/4263/4038.

Soulé, M., and Wilcox, B. (Eds.). (1980). Conservation Biology: An Evolutionary-Ecological Perspective.SinauerAssociates, Sunderland, Massachusetts. URL:https:/ /www.gislounge.com/gis-used-conservation-biology/

Stein, B.A. (1997). Designing information systems to support biodiversity conservation. In: Hawksworth, D.L., Kirk, P.M. and Clarke, S.D. (Eds), Biodiversity Information Needs and Options, pp. 5-20. Proceedings of the 1996 International Workshop on Biodiversity Information. CAB International. URL: www.cbd.int/doc/articles/2003/A-00152.pdf.

SUN. (2014). URL: www0.sun.ac.za/pgstudies/postgraduate-programm and www.eric.gov/?id=EJ809329

Tweddle, D., R. Bills, E. Swartz, W. Coetzer, L. da Costa, J. Engelbrecht, J. Cambray, B. Marshall, D. Impson, P.H. Skelton, W.R.T Darwall, K.S. Smith. 2009. The status and distribution of freshwaterfishes. Pp. 21-37 in the Status and Distribution of Freshwater Biodiversity in Southern Africa (W.R.T. Darwall, K.G. Smith, D. Tweddle, and P.H. Skelton, eds.). International Union for the Conservation of Nature, Gland. URL: www.journals.ku.edu/index.php/jbi/article/viewFile/4263/4038.

UNEP. (1992). Convention on Biodiversity. Nairobi, Kenya: UNEP Environmental Laws and Institutions Programme Activity Center. URL: www.cbd.int/doc/articles/2003/A-00152.pdf. 
Vreugdenhil,D., Terborgh, J., Cleef, A. M., Sinitsyn, M.,Boere, G.C., Archaga, V.L., and Prins, H.H.T. 2003. Comprehensive Protected Areas System: Composition and Monitoring. Shepherdstown, USA: World Institute for Conservation and Environment. Web: https://portals.iucn.org/library/efiles/documents/2003-031.pdf

Wade, R.2006. Spirit of the web: the age of information from telegraph to the internet. Toronto: T. Allen. URL: https://www.amazon.ca/Spirit-Web-Information-Telegraph-Internet/dp/0887622275

Waset. (2014). URL: www.waset.org/publications/14873

Watson, R. T., Boudreau, M.-C., and Chen, A. J. (2010, March). Information Systems and Environmentally Sustainable Development. MIS Quarterly, 34(1), pp. 23-38. URL:https://www.gislounge.com/gis-used-conservation-biology/. And www.terry.uga.edu/directory/profile/mcboudre/

WFP (Water-Forest-Park). (2012). URL: http://sites.path.org/water/water/hwts/markets/basket-of-goods-approach-in-kenya/

Wikipedia-c. (2014). URL: en.m.wikipedia.org/wiki/Information system

Wildlife (Conservation and Security) Act. 2012, Article 2(15), Legislative and Parliamentary Affairs Division, Ministry of Law, Justice, and Parliamentary, People's Republic of Bangladesh, Dhaka, Bangladesh.

Wildlife Conservation and Security Act, 2012, Article 2(14), Legislative and Parliamentary Affairs Division, Ministry of Law, Justice, and Parliamentary, People's Republic of Bangladesh, Dhaka, Bangladesh.

Wildlife Conservation and Security Act, 2012, Article 2(43), Legislative and Parliamentary Affairs Division, Ministry of Law, Justice, and Parliamentary, People's Republic of Bangladesh, Dhaka, Bangladesh.

Wilson, E.O. 2003. Biodiversity in the information age. Issues in science and Technology 19 (4). 45-47.

Wurman, R.S.1989. Information Anxiety. New York and Toronto: Doubleday. 
MJMBR listed in CSE member's journals database

http://www.councilscienceeditors.org/about/members-journals/

Indexed in Google Scholar

https://scholar.google.com/citations?hl=enanduser=JH23W_8AAAAI

MJMBR Following the ICMJE Recommendations (list date 7/1/14)

http://www.icmje.org/recommendations/

\section{RoMEO: This is a RoMEO blue journal \\ http:/ / www.sherpa.ac.uk/romeo/search.php?issn=2313-0008 \\ Author's Pre-print: author cannot archive pre-print (ie pre-refereeing) \\ Author's Post-print: author cannot archive post-print (ie final draft post-refereeing) \\ Publisher's Version/PDF: author can archive publisher's version/PDF}

\section{(c) $(1) \Theta$}

Licensing: CC-BY-NC 4.0 International License

This journal is licensed under a Creative Commons Attribution-NonCommercial 4.0 International License. Articles can be read and shared for noncommercial purposes under the following conditions:

- BY: Attribution must be given to the original source (Attribution)

- NC: Works may not be used for commercial purposes (Noncommercial)

This license lets others remix, tweak, and build upon your work non-commercially, and although their new works must also acknowledge you and be non-commercial, they don't have to license their derivative works on the same terms.

License Deed Link: http://creativecommons.org/licenses/by-nc/4.0/

Legal Code Link: http://creativecommons.org/licenses/by-nc/4.0/legalcode

MJMBR uses the CC BY-NC to protect the author's work from misuse. 